\title{
ANALYSIS OF PERCEIVED QUALITY OF EDUCATION SERVICE
}

\section{Murwatiningsih}

Fakulty of Economics, Universitas Negeri Semarang, Semarang, Indonesia

\begin{tabular}{l} 
Info Artikel \\
\hline Sejarah Artikel: \\
Diterima Januari 2014 \\
Disetujui Februanri 2014 \\
Dipublikasikan Maret 2014 \\
\hline Keywords: \\
Quality; \\
Service; \\
Treat Education \\
organizational change \\
\hline
\end{tabular}

\section{ANALISIS PERSEPSI KUALITAS JASA LAYANAN PENDIDIKAN}

\begin{abstract}
Abstrak
Penelitian ini bertujuan untuk mengetahui gambaran deskriptif tentang kualitas jasa layanan pendidikan. Lokasi penelitian ini di Fakultas Ekonomi, dan obyek penelitiannya adalah mahasiswa semester VII Fakultas Ekonomi Universitas Negeri Semarang. Populasinya sebanyak 620 mahasiswa pada tahun akademik 2014/2015. Pengambilan sampel dengan teknik cluster proportional random sampling sebanyak 186 orang. Metoda pengumpulan data menggunakan kuesioner dan metoda analisis data menggunakan statistik non parametrik (deskriptif persentase). Hasil penelitian ini menunjukkan bahwa kualitas jasa layanan pendidikan di Fakultas Ekonomi Universitas Negeri Semarang dilihat dari dimensi relevansi, efisiensi, efektifitas, akuntabilitas, ketanggapan, kreatifitas, produktifitas, kemampuan akademik, empati, dan penampilan, dipersepsikan oleh mahasiswa secara keseluruhan sudah baik. Namun hasil ini belum optimal, terutama pada dimensi relevansi, efisiensi dan efektifitas.
\end{abstract}

JEL Classification: M3, M31

${ }^{\square}$ Alamat korespondensi : 


\section{INTRODUCTION}

An institution is said to be successful in managing itself is when it is able to achieve the short term and long term purposes at the proper effectiveness level. The short term purpose can be achieved at the proper effectiveness level when the institution exposes high productivity, efficient, and able to bring satisfaction to the owner, member, customer, and other pertinent parties. On the other hand, the long term purpose can be achieved at the proper effectiveness level when the institution is able to survive. In short, the short term purpose is correlated to productivity, growth, adaptability, satisfaction, and efficiency, while the long term purpose is dealing with survival issue. Those elaborations above raise a problem of the low appraisal towards the education quality in Indonesia.

Tampubolon (2001) explained that the low quality of education in Indonesia due to the instability of the teachers education system. Around 20 types of teachers' education system have been applied since the independence era until today, similar to the transition of IKIP (Teachers Training Institute) into University. It is closely related to the low living standard and qualification of the teachers. Besides, a research from "Asia Week" (1999) revealed that the lecturers' salary in Indonesia was the lowest in Asia Pacific. Thus, to improve the quality of education, one of the indicators is by increasing the quality and reward towards teacher/lecturer profession. The low quality of Indonesian education system shows some shortcomings in the education management aspect.

Those shortcomings also expose the low quality of the education service. It might be rather difficult to generalize the problem at various types and levels of education, yet it could also be assumed that the education system drawback and service quality inferiority also occur in many higher education institutions and mainly at the Economic faculty of Universitas Negeri Semarang. Factors of higher education service which are assumed to have significant influence towards education service consist of 5, i.e. 1) Administration Service; 2) Curricular Service; 3) Research Service; 4) Community Devotion Service; 5) Extracurricular Service (Tampubolon, 2001). The five services are invested, civilized within the students self and live during their study which aim to develop academic ability and skill and also to make them professional.

According to Cheng (1995), education service quality is reflected through inputprocess-output which meets the explicit and implicit expectations. The five factors themselves consist of those which facilitate the education service and those which impede. A variety of physical, social, and psychological reality within the factors would color the education process. Through a deeper observation, actually the quality of Indonesian education service is not far beyond those abroad. The main issue is that the educational approach practiced here tends to implement producer approach than customer approach.

Customer approach studies various characteristics of customers needs in education. Meanwhile, the customers characteristics for the education service in Indonesia have not been explored due to the assumption that the customers are homogeneous user and rather careless with educational institution differentiation from one and another. One of the indications exposed showed that the graduates are unable to face the current challenges as seen by the society who hires the graduates. This is the product of higher education institutions which have not achieved the expected effectiveness level including the education service quality. Therefore, a comprehensive education service quality measurement needs to be carried out in the pertinent institution. Based on those descriptions, a research on the analysis of education service quality perception at Economic faculty of Universitas Negeri Semarang is proposed.

Problems identified in this research is attempted to be solved by management science through Total Quality Management 
(TQM) perspective. This approach is selected considering the function and role of Universitas Negeri Semarang as the producer in the educational field which produce educational and professional workers (product). The main issue for Universitas Negeri Semarang through Economic faculty as producer is how to produce qualified product which meets the users' expectations. Hence, the TQM perspective approach implications can be clearly seen in the application of this research proposal.

Based on the previous background of study, some research problems can be drawn as follows: How is the descriptive view of administrative service quality that is related to public policy, leadership, public administration, and academic administration according to the perceptions of Economic faculty of Universitas Negeri Semarang students

Juran (1995) stated that quality means the conformability with usage. Perceived quality is image and product reputation and corporate responsibility towards the quality (Tjiptono, 1998). Meanwhile, in the Standard of Terminology book about quality, i.e. ISO 8402 Quality Vocabulary year 1986, quality means: "Quality is the totality of features and characteristics on is ability to satisfy stated or implied needs". So, quality is a specific output which meets the usage for the customers' (users') satisfaction. Study product in this research is service product; then it needs to be explained the definition of educational service quality. According to Sallis (1993), service quality means: "Quality can be defined as that which best satisfies and exceeds customers' needs and wants". Hence, educational service quality implicitly means to give satisfaction to what is demanded and expected by customers. Ross (1993) explained that service quality in the educational service can be approached with the implementation of Total Quality Management (TQM).

There are three universal processes of service management in TQM which have been generalized into universal stages arrangement.
The stages include quality planning, quality control, and quality improvement (Juran, 1995). TQM approach covers five principle dimensions (Tjiptono, 1998) which can be applied to measure and determine service quality in Higher Education Institution, i.e.: 1) Tangibles, which includes physical facility, equipment, employee, lecturer, and communication medium; 2) reliability, which includes capability in giving quick, appropriate, satisfying service based on what has been promised. In the education world, this dimension is reflected on curriculum, lecturing process, study guidance, learning achievement appraisal, and so forth; 3) responsiveness, which is the willingness to assist the students and give responsive service. Here means, Rector, Rector Associate, Dean, and Dean Associates, Head and Secretary of Department, Head of Study Program, Lecturer, and other structural officials should be easily contacted. Likewise, the educational facilities should be accessible by the students. When service failure occurs, the capability in conducting fast and professional improvements can create positive quality perceptions. 4) assurance, which covers knowledge, competence, politeness, and respect to customers, and reliable characteristic owned by the staffs and 5) empathy, which is facilitation in carrying relation, good communication, personal attention, and understanding towards customers' needs. The lecturer should know the students' names and academic advisors should know their function.

Educational service in the Higher Education Institution according to Tampubolon (2001) covers five factors which are assumed to have significant influences to the educational service quality. Those five factors include: 1) administration Service, i.e. direct administration service activities for the students to support curricular, research, and community devotion services, while the indirect ones to support students' interest development, students' wealthy development, and work field guidance; 2) curricular Service, which covers 
curriculum, syllabus, lecture quality planning, learning material unit, material presentation, evaluation, practice work, and guidance. 3) Research Service, includes research guidance from the planning, execution, and research output seminar; 4) community Devotion Service, covers activities to help public community, mainly to those in the low class economy or education by implementing sciences and skills which includes curricular and research services; 5) extracurricular Service covers students' activities that support curricular service. Educational field can apply Total Quality Management to solve crucial educational problems as an attempt of improving competences for establishment (Sallis, 1997).

Nowadays, Indonesia is facing these following challenges: weaknesses in the education fairdistribution andacquisition, educational quality and relevance, and educational management. To overcome those problems, DIKTI has decided to create some problem solving policies by establishing Higher Education Development Support (HEDS) to improve higher education quality and management with the assistance of US-AID (United States Agency for International Development) and JICA (Japanese International Cooperation Agency).

Besides, the government has also changed some policies as in KPPT JP Year 1999 2005 which consists of: a) continuous quality improvement, b) Higher Education Institution Autonomy through BHMN, c) National Accreditation Board (BAN). The explanation above has shown that production system and process and also the product, as covered in the five educational service factors, have become the main focus in determining educational service quality. Thus, a qualified higher education institution has to be able to manage the system, process, and product well to meet the customers (students) needs and wishes towards educational service. The theoretical framework of this research in Figure 1

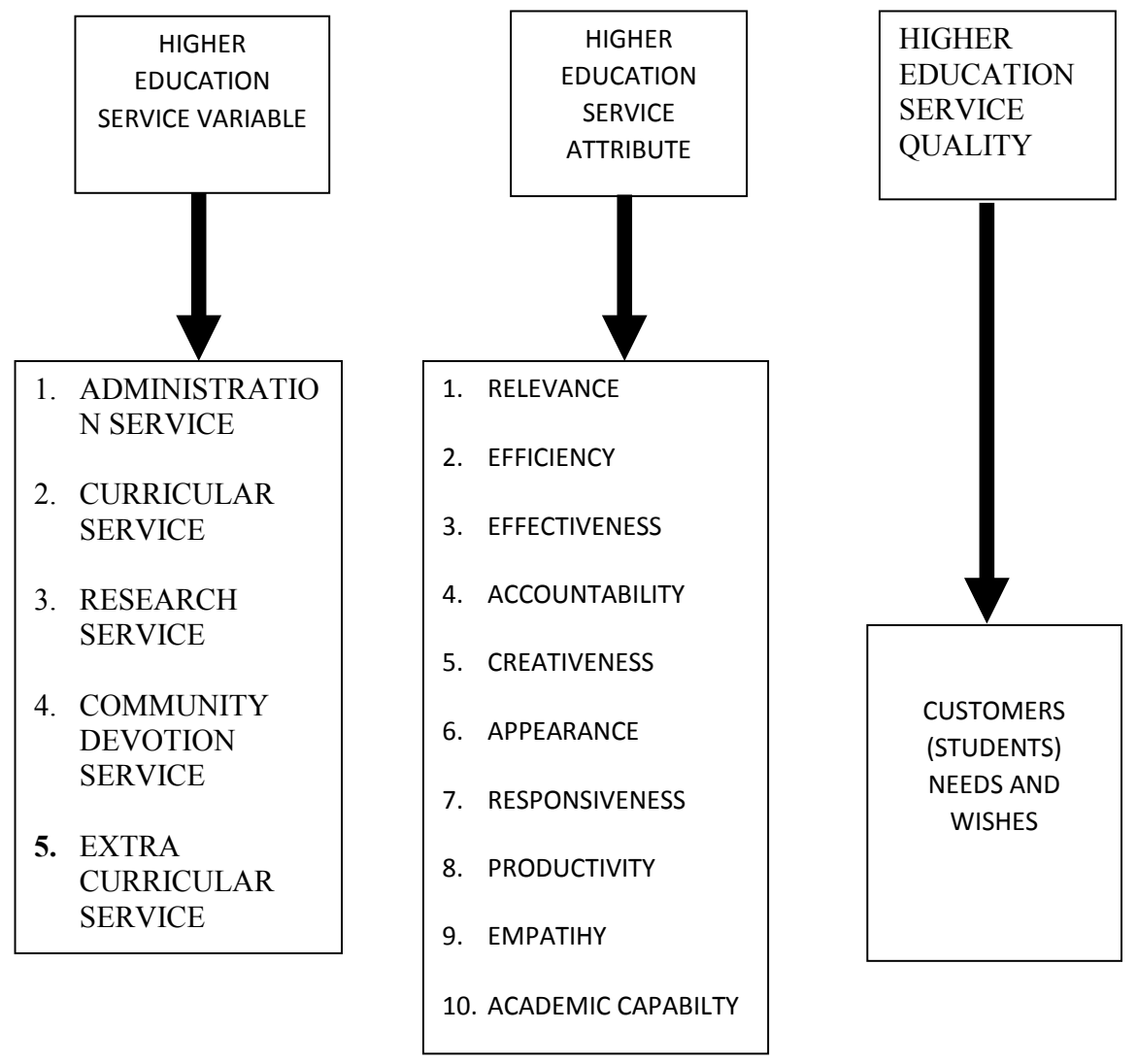

Figure 1. Theoretical Framework 


\section{METHOD}

The population of this research is all the semester VII students of Economic faculty of Universitas Negeri Semarang who meets the following criteria: active students who have accomplished field job (KKN), teaching training (PPL), or job training (PKL) and finished their research guidance. The decision in the number and technique of sampling employed Slovin approach (Umar, 1997) and cluster proportional random sampling technique. A detailed population and sample for this research in Table 1. Research Variable: variable, indicator, and measurement scale are explained in Table 2.

The data used in this research included primary and secondary data. The primary data were acquired from the respondents based on the given questionnaire which covered educational service quality variables like administration, curricular, research, community devotion, and extracurricular services, while the secondary ones covered the number of the Economic faculty students based on their department and study program. Type of data in this research were quantitative data, hence, the researcher applied statistic non parametric technique in the analysis.

Questionnaire and documentation method. Questionnaire was used to collect the educational service data which included administration, curricular, research, community devotion, and extracurricular services. Documentation method was applied to find out the number of students in Economic faculty based on their department and study program. The measurement scale was determined with itemized rating scale in the form of Likert scale, with five scales, i.e.: Very Good $=5$; Good $=$ 4; Fair $=3$; Poor $=2$; Very Poor $=1$. Validity was tested with two systems, content validity and construct validity at the significance level of $5 \%$. Reliability was tested with alpha coefficient formulation from Cronbach with minimum coefficient 0.50 .

Data Analysis Method: data analysis method employed in this research was statistic non parametric (descriptive/percentage), which was determined through these in Table 3.

\section{RESULT AND DISCUSSION}

This section will elaborate the research output and discussion on the educational service quality at Faculty of Economic Universitas Negeri Semarang. The discussion is important to figure out the descriptive view of educational service quality which covered 1) administration service, 2) curricular service, 3) research service, 4) community devotion service, and extracurricular service based on the perceptions

Table 1. Research Population and Sample

\begin{tabular}{clccc}
\hline NO. & \multicolumn{1}{c}{ STUDY PROGRAM } & $\begin{array}{c}\text { POPULATION } \\
\text { (student) }\end{array}$ & $\begin{array}{c}\text { FRACTION (f) } \\
\text { SCORE }\end{array}$ & $\begin{array}{c}\text { SAMPLE } \\
\text { (n) }\end{array}$ \\
\hline 1. & Accounting Economic Education. & 80 & 0,18 & 18 \\
2. & Cooperative Economic Education. & 28 & 0,07 & 7 \\
3. & Office Administration Economic & 50 & 0,11 & 11 \\
& Education. & & & \\
4. & Management. & 116 & 0,27 & 27 \\
5. & Development Economic. & 42 & 0,10 & 10 \\
6. & Accounting. & 116 & 0,27 & 27 \\
\hline & Total & 432 & 1,00 & 100 \\
\hline
\end{tabular}

Source: data processed (2014) 
Table 2. Research Variable Identification

\begin{tabular}{|c|c|c|c|c|}
\hline NO. & VARIABLE & INDICATOR & MEASUREMENT & $\begin{array}{l}\text { MEASUREMENT } \\
\text { SCALE }\end{array}$ \\
\hline 1. & $\begin{array}{l}\text { Administration } \\
\text { Service. }\end{array}$ & $\begin{array}{l}\text { Academic administration } \\
\text { Public administration }\end{array}$ & Relevance, & Ordinal \\
\hline 2. & Curricular Service. & $\begin{array}{l}\text { Academic manual, } \\
\text { Lecture, } \\
\text { Facility and learning } \\
\text { source, } \\
\text { Department information } \\
\text { system, }\end{array}$ & Effectiveness, & Ordinal \\
\hline 3. & Research Service. & $\begin{array}{l}\text { Research manual, } \\
\text { Guidance execution, } \\
\text { Research activity facility, } \\
\text { Administration / research } \\
\text { information system, }\end{array}$ & Responsiveness, & Ordinal \\
\hline 4. & $\begin{array}{l}\text { Community } \\
\text { devotion service. }\end{array}$ & $\begin{array}{l}\text { Devotion manual, } \\
\text { Devotion execution, } \\
\text { Devotion activity facility, } \\
\text { Administration / devotion } \\
\text { information system, }\end{array}$ & $\begin{array}{l}\text { Creativity, } \\
\text { Productivity, }\end{array}$ & Ordinal \\
\hline 5. & $\begin{array}{l}\text { Extracurricular } \\
\text { service. }\end{array}$ & $\begin{array}{l}\text { Extracurricular activity } \\
\text { manual, } \\
\text { Extracurricular activity } \\
\text { execution, } \\
\text { Extracurricular activity } \\
\text { facility. }\end{array}$ & $\begin{array}{l}\text { Academic capability, } \\
\text { Empathy, } \\
\text { Appearance. }\end{array}$ & Ordinal \\
\hline
\end{tabular}

Source: data processed (2014)

Table 3. Interval

\begin{tabular}{ccc}
\hline NO. & Data Interval $(\%)$ & Category \\
\hline 1. & $81-100$ & Very Good \\
2. & $61-80$ & Good \\
3. & $41-60$ & Fair \\
4. & $21-40$ & Poor \\
5. & $0-20$ & Very Poor \\
\hline
\end{tabular}

Source: data processed (2014) 
of Faculty of Economic, Universitas Negeri Semarang students. The overall data processing output on the education service quality at Economic faculty of Universitas Negeri Semarang based on the students perceptions can be seen through the Graphic 1 .

Graphic 1. Showed that around 2\% of the Economic Faculty students' perceived the educational service at the very good criteria, $40 \%$ good, $46 \%$ fair, $11 \%$ poor, and $1 \%$ very poor. The result shows that the educational service as perceived by the Economic Faculty students is at overall good. It can be seen from the students' perception percentage which tends to be in the area of very good, good, and fair criteria. However, the educational service has not optimally met their expectation for there is still some perception percentage occurs in the poor and very poor area. To see the descriptive view partially based on each variable (administration, curricular, research, community devotion, and extracurricular services) is presented as follows.

\section{Administration Service}

Administration service means a service given by the Economic Faculty of Universitas NegeriSemarang to thestudents on theacademic and public administration services. To see the description of whether those administration services have given satisfaction to the students, some measurement criteria like relevance, efficiency, effectiveness, accountability, responsiveness, creativity, productivity, academic capability, empathy, appearance were used. Based on the data processed output, the overall students perceptions towards the administration service given by the Economic Faculty of Universitas Negeri Semarang is in Graphic 2.

Graphic 2. showed that around 2\% of the Economic Faculty students perceived very good for the administration service, $35 \%$ good, $46 \%$ fair, $16 \%$ poor, and $1 \%$ very poor. Overall, the Economic Faculty is fair enough is giving administration service as can be seen from the students perception percentage which mostly in the area of very good, good, and fair criteria. However, the administration service given is not optimal yet due to the availability of some small perception percentage in the area of poor and very poor criteria. The data processed output on the administration service at Economic Faculty of Universitas Negeri Semarang as perceived by the students based on the service quality dimensions is presented in Table 4.

Table 4. showed that the administration service is quite efficient as can be seen $1 \%$ students stated very good, 29\% good, and 49\% fair. However, $20 \%$ students still perceived poor and $1 \%$ very poor that shows the service is still needed to be optimized. Likewise, the administration service is also quite effective as can be seen from the $2 \%$ students stated that it is very good, $28 \%$ good, and $46 \%$ fair. But it has also not optimized yet for there are $23 \%$ poor and

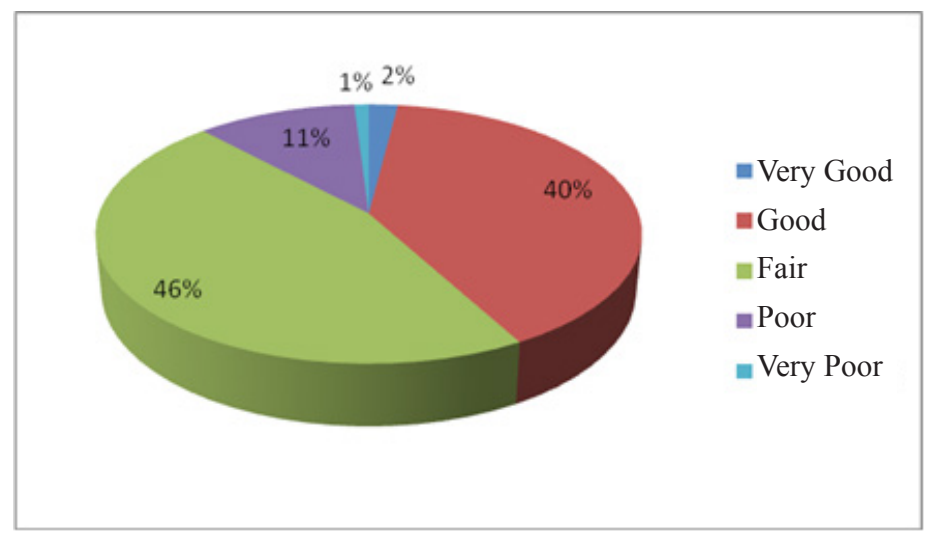

Graphic 1. Percentage of Education Service Quality at Economic Faculty of Universitas Negeri Semarang 
Murwatiningsih / Analysis of Perceived Quality of Education...

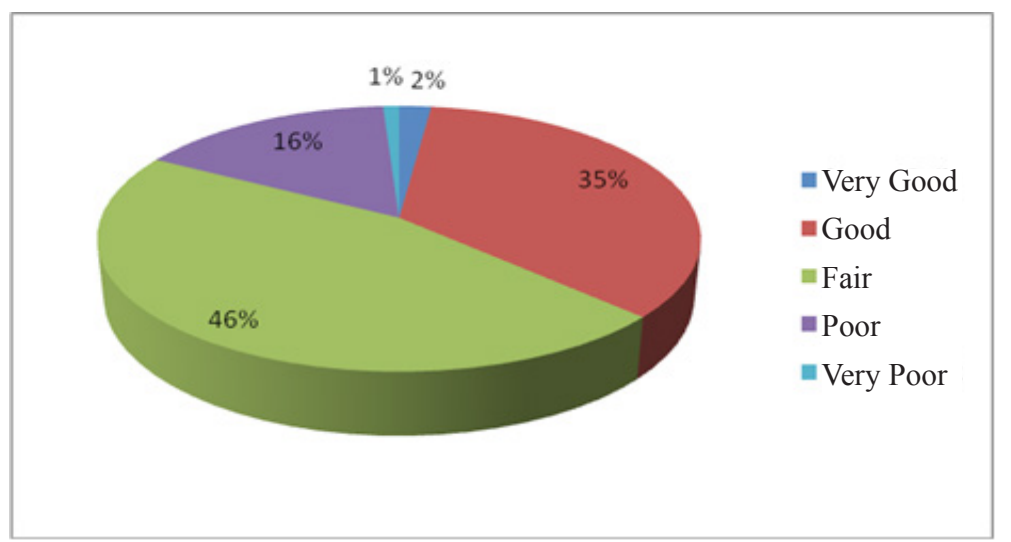

Graphic 2. Percentage of Administration Service

Table 4. Percentage of Administration Service based on the Service Quality Dimensions

\begin{tabular}{llccccc}
\hline Variable & $\begin{array}{l}\text { Measurement } \\
\text { Criteria (\%) }\end{array}$ & $\begin{array}{c}\text { Very Good } \\
(\%)\end{array}$ & $\begin{array}{c}\text { Good } \\
(\%)\end{array}$ & $\begin{array}{c}\text { Fair } \\
(\%)\end{array}$ & $\begin{array}{c}\text { Poor } \\
(\%)\end{array}$ & $\begin{array}{c}\text { Very Poor } \\
(\%)\end{array}$ \\
\hline Administration & Relevance & 3 & 35 & 51 & 10 & 1 \\
Service & Efficiency & 1 & 29 & 49 & 20 & 1 \\
& Effectiveness & 2 & 28 & 46 & 23 & 1 \\
& Accountability & 1 & 30 & 51 & 17 & 1 \\
& Responsiveness & 3 & 39 & 41 & 15 & 2 \\
& Creativity & 2 & 32 & 48 & 17 & 1 \\
& Productivity & 1 & 43 & 37 & 18 & 1 \\
& Academic Capabil- & 1 & 44 & 45 & 9 & 1 \\
& ity & & & & & \\
& Empathy & 4 & 32 & 48 & 15 & 1 \\
& Appearance & 2 & 39 & 44 & 14 & 1 \\
& Average & 2 & 35 & 46 & 16 & 1 \\
\hline
\end{tabular}

Source: data processed (2014)

$1 \%$ very poor perceptions. From the efficiency measurement view, this administration service is also not optimum yet which means the sources usage (energy, time, financial, and so forth) have not reflected the expected efficiency level. While the ineffectiveness of the administration service showed that system planning, method, and process/procedure executions are not optimum with the expected output. It means that the good management from the quality and quantity sides has not been optimized for the administration service activity. However, the relevance, accountability, creativity, productivity, responsiveness, academic capability, and appearance dimensions have been considered as good in giving administration service (the percentage for very good, good, and fair is above $61 \%$ ). It means that the officials have high responsibility and concern towards the fulfillment of the customers' (students') administration service need. The finding is in line with Tampubolon (2001) who stated that administration service is service activity to the students which directly supports curricular, research, and community devotion services and indirectly supports the students' interest development. Likewise, the finding is also in line with Parasuraman in 
Tjiptono (1998) who stated that service quality is determined with some dimensions include responsiveness, empathy, and tangibles.

\section{Curricular Service}

Curricular service is defined as a service given by the Economic Faculty of Universitas Negeri Semarang to the students in the area of academic manual, lecturing, facility and learning source, department information system services. To see the description whether the curricular service has given satisfaction to the students, relevance, efficiency, effectiveness, accountability, responsiveness, creativity, productivity, academic capability, empathy, and appearance measurement criteria were employed. Based on the data processed output of the curricular service of Economic Faculty of Universitas Negeri Semarang, the overall students' perceptions are in Graphic 3.

Graphic 3. showed that the Economic Faculty of Universitas Negeri Semarang students' perceptions towards curricular service are $2 \%$ very good, $42 \%$ good, $44 \%$ fair, $11 \%$ poor, and $1 \%$ very poor. Overall, the curricular service given by Economic Faculty is already good as can be seen from the students' perception which tends to be in the very good, good, and fair criteria. However, it still needs some improvements as expected by the students for there are still poor and very poor perceptions. The data processed output of the curricular service given by Economic Faculty of
Universitas Negeri Semarang as perceived by the students based on the service quality dimensions in Table 5.

Table 4. showed the curricular service is already good (the percentage in the very good, good and fair criteria is above 61\%) in the dimensions of relevance, efficiency, effectiveness, accountability, responsiveness, creativity, productivity, academic capability, empathy, and appearance. This finding is in line with Tampubolon (2001) who stated that curricular service includes curriculum, syllabus, learning material (academic manual), and lecturing. Likewise, it also in line with Parasuraman in Tjiptono (1998) who stated that service quality is determined with tangibles, reliability, responsiveness, assurance, and empathy. However, the curricular service based on those dimensions has not been optimized yet as shown by some percentages which are still exist in the poor and very poor criteria. The relevance dimension tends to have higher poor and very poor percentage than other dimensions. It indicates the low relevance between system planning, method, and process/procedure with the output. It means the curricular service has not been optimized yet both from the quantity and quality of the customers' (students') needs fulfillment.

\section{Research Service}

Research service is defined as a service given by Economic Faculty of Universitas Negeri Semarang to the students in the area

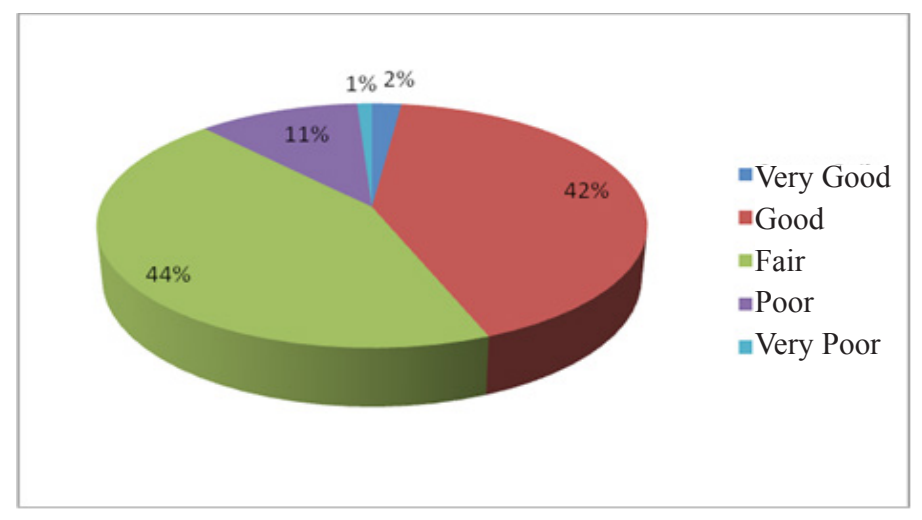

Graphic 3. Percentage of Curricular Service 
Murwatiningsih / Analysis of Perceived Quality of Education...

Table 5. Percentage of Curricular Service based on Service Quality Dimensions

\begin{tabular}{llccccc}
\hline Variable & $\begin{array}{c}\text { Measurement Criteria } \\
(\%)\end{array}$ & $\begin{array}{c}\text { Very Good } \\
(\%)\end{array}$ & $\begin{array}{c}\text { Good } \\
(\mathbf{\%})\end{array}$ & $\begin{array}{c}\text { Fair } \\
(\mathbf{\%})\end{array}$ & $\begin{array}{c}\text { Poor } \\
(\mathbf{\%})\end{array}$ & $\begin{array}{c}\text { Very Poor } \\
(\%)\end{array}$ \\
\hline Service Quality & Relevance & 2 & 40 & 38 & 18 & 2 \\
& Efficiency & 1 & 41 & 44 & 13 & 1 \\
& Effectiveness & 1 & 38 & 47 & 12 & 2 \\
& Accountability & 2 & 37 & 50 & 10 & 1 \\
& Responsiveness & 1 & 45 & 41 & 12 & 1 \\
& Creativity & 2 & 43 & 42 & 12 & 1 \\
& Productivity & 6 & 42 & 44 & 7 & 1 \\
& Academic Capability & 3 & 48 & 42 & 6 & 1 \\
& Empathy & 1 & 42 & 44 & 12 & 1 \\
Appearance & 1 & 45 & 48 & 5 & 1 \\
Average & 2 & 42 & 44 & 11 & 1 \\
\hline
\end{tabular}

Source: data processed (2014)

of research manual, research guidance service, research equipment/facility service, research information system service. To see whether the research service has brought satisfaction to the students, the measurement criteria of relevance, efficiency, effectiveness, accountability, responsiveness, creativity, productivity, academic capability, empathy, and appearance are employed. The overall data processed output of the research service given by the Economic Faculty of Universitas Negeri Semarang as perceived by the students is drawn in Graphic 4.

Graphic 4. indicated that the research service given by the Economic Faculty of Universitas Negeri Semarang to the students is considered to be good as indicated with the $1 \%$ very good, $42 \%$ good, and $45 \%$ fair percentages. However, there are still $11 \%$ poor and $1 \%$ very poor perceptions which indicate that the service is still need to be improved to meet the students expectation. The data processed output of research service of Economic Faculty of Universitas Negeri Semarang as perceived by the students in Table 6.

Table 6. indicated that the research service is already good (the percentage of very good, good, and fair criteria is above 61\%) in the relevance, efficiency, effectiveness, accountability, responsiveness, creativity, productivity, academic capability, empathy, and appearance service dimensions. This finding is in line with Tampubolon (2001) who stated that research service covers guidance from the planning, execution, to research output seminar. Likewise, it also in line with Parasuraman in Tjiptono (1998) who explained that service quality is determined with tangibles, reliability, responsiveness, assurance, and empathy. However, the relevance and effectiveness dimensions tend to own higher poor and very poor percentage than others. It indicates the existence of small relevance between system planning, method, process/procedure with the output. Similarly, the research service has not reflected the high level of effectiveness which means the system planning, method, and process/procedure with the output during the research guiding activity is not optimal yet.

\section{Community Devotion Service}

Community devotion service is defined as a service given by the Economic Faculty of Universitas Negeri Semarang to the students in the area of community devotion manual service, community devotion program service, community devotion execution service, 


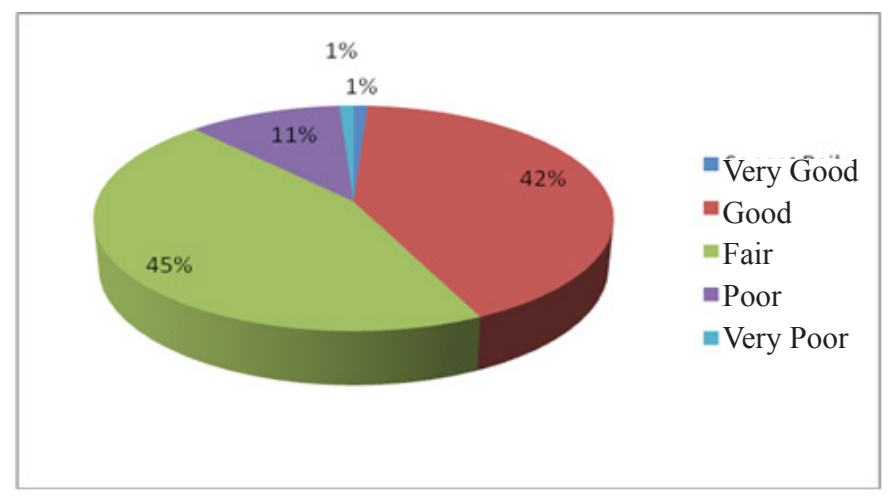

Graphic 4. Percentage of Research Service

Table 6. Percentage of Research Service based on the Service Quality Dimensions

\begin{tabular}{llccccc}
\hline Variable & $\begin{array}{l}\text { Measurement } \\
\text { Criteriaz }\end{array}$ & $\begin{array}{c}\text { Very Good } \\
(\%)\end{array}$ & $\begin{array}{c}\text { Good } \\
(\%)\end{array}$ & $\begin{array}{c}\text { Fair } \\
(\%)\end{array}$ & $\begin{array}{c}\text { Poor } \\
(\%)\end{array}$ & $\begin{array}{c}\text { Very Poor } \\
(\%)\end{array}$ \\
\hline Research & Relevance & 1 & 39 & 44 & 15 & 1 \\
Service & Efficiency & 1 & 37 & 47 & 14 & 1 \\
& az & 1 & 31 & 49 & 18 & 1 \\
& Accountability & 1 & 41 & 44 & 13 & 1 \\
& Responsiveness & 1 & 43 & 44 & 11 & 1 \\
& Creativity & 1 & 45 & 44 & 9 & 1 \\
& Productivity & 1 & 43 & 46 & 9 & 1 \\
& Academic Capability & 1 & 49 & 42 & 7 & 1 \\
& Empathy & 1 & 45 & 42 & 11 & 1 \\
& Appearance & 1 & 48 & 44 & 6 & 1 \\
& Average & 1 & 42 & 45 & 11 & 1 \\
\hline
\end{tabular}

Source: data processed (2014)

community devotion facility/equipment service, community devotion information system service. To see the description of whether the community devotion service has given satisfaction to the students, measurement criteria of relevance, efficiency, effectiveness, accountability, responsiveness, creativity, productivity, academic capability, empathy, and appearance are employed. The data processed output of community devotion service given by the Economic Faculty of Universitas Negeri Semarang as perceived by the students is described in Graphic 5

Graphic 5. showed $1 \%$ students perceived the community devotion service given by Economic Faculty of Universitas
Negeri Semarang is very good, 36\% good, $52 \%$ fair, $10 \%$ poor, and $1 \%$ very poor. It indicated that the students' perception towards the community devotion service is already good, but there are still need some optimization due to the availability of some small number of percentages in the area of poor and very poor. The data processed output of the community devotion service give by Economic Faculty of Universitas Negeri Semarang as perceived by the students in in Table 7.

Table 7. showed that the community devotion service given by the Economic Faculty of Universitas Negeri Semarang is perceived as already good (the percentage for very good, good, and fair criteria is above 61\%) 


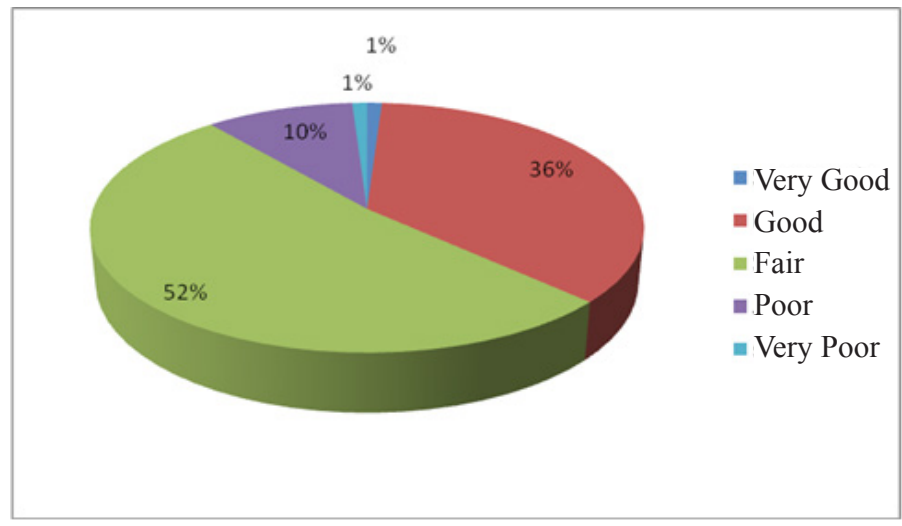

Graphic 5. Percentage of Community Devotion Service

Table 7. Percentage of Community Devotion Service based on the Service Quality Dimensions

\begin{tabular}{llccccc}
\hline Variable & Measurement Criteria & $\begin{array}{c}\text { VeryGood } \\
(\mathbf{\%})\end{array}$ & $\begin{array}{c}\text { Good } \\
(\mathbf{\%})\end{array}$ & $\begin{array}{c}\text { Fair } \\
(\mathbf{\%})\end{array}$ & $\begin{array}{c}\text { Poor } \\
(\mathbf{\%})\end{array}$ & $\begin{array}{c}\text { Very Poor } \\
(\%)\end{array}$ \\
\hline Community & Relevance & 1 & 32 & 51 & 15 & 1 \\
Devotion Service & Efficiency & 1 & 33 & 52 & 13 & 1 \\
& Effectiveness & 1 & 36 & 51 & 11 & 1 \\
& Accountability & 1 & 34 & 53 & 11 & 1 \\
& Responsiveness & 1 & 37 & 52 & 9 & 1 \\
& Creativity & 1 & 38 & 54 & 6 & 1 \\
& Productivity & 1 & 38 & 52 & 9 & - \\
& Academic Capability & 2 & 40 & 49 & 9 & - \\
& Empathy & 1 & 38 & 50 & 10 & 1 \\
& Appearance & - & 35 & 56 & 7 & 2 \\
& Average & 1 & 36 & 52 & 10 & 1 \\
\hline
\end{tabular}

Source: data processed (2014)

in the relevance, efficiency, effectiveness, accountability, responsiveness, creativity, productivity, academic capability, empathy, and appearance service dimensions. The finding is in line with Tampubolon (2001) who stated that community devotion service will happen when science and curricular service skill and research service are applied to the society. Likewise, it also in line with Parasuraman in Tjiptono (1998) who explained that service quality is determined by tangibles, reliability, responsiveness, assurance, and empathy. However, the relevance and efficiency dimensions tend to have higher poor and very poor percentage than the others. It indicates the low relevance between system planning, method, and process/procedure with the output. In addition, the efficiency level is also not optimum yet due to the realizations are still in the form of curricular activities.

\section{Extracurricular Service}

Extracurricular service is defined as a service given by Economic Faculty of Universitas Negeri Semarang to the students in the area of extracurricular activity manual service, extracurricular program service, extracurricular program execution service, and extracurricular facility/equipment service. To see the description of whether the extracurricular service has given satisfaction to the students, measurement 
criteria of relevance, efficiency, effectiveness, accountability, responsiveness, creativity, productivity, academic capability, empathy, and appearance are employed. The data processed output of the extracurricular service given as perceived by the students is drawn in Graphic 6.

Graphic 6. showed that the Economic Faculty students' perceptions on the extra curricular service given are $1 \%$ very good, $33 \%$ good, $49 \%$ fair, $15 \%$ poor, and $2 \%$ very poor. Overall, the Economic Faculty is quite good in giving extracurricular service to the students as can be seen from the percentage which mostly in the area of very good, good, and fair criteria. However, the availability of some small percentages in the area of poor and very poor means that the service given is not optimum yet as expected by the students. The data processed output on the extracurricular service given by the Economic Faculty of Universitas Negeri Semarang based on the service quality dimensions in Table 8.

Table 8. showed that the extracurricular service in the relevance, efficiency, effectiveness, accountability, responsiveness, creativity, productivity, empathy, and appearance dimensions is fair (the percentage for very good, good, and fair criteria is above $41 \%$. Meanwhile, the academic capability indicated good perception. This finding is in line with Tampubolon (2001) who stated that extracurricular service is an activity which supports extracurricular service. Likewise, it also in line with Parasuraman in Tjiptono (1998) since the five dimensions (tangibles, reliability, responsibility, assurance, and empathy) determines the fulfillment of the service quality.

However, the dimensions of relevance, efficiency, effectiveness, accountability, responsiveness, creativity, productivity, and empathy still tend to have higher poor and very poor percentage compared to those in the academic capability and appearance dimensions. It indicated that there is still an irrelevance between system planning, method, and process/procedure with the output. Besides, the coordination between department and its students' activity units have not been optimized and integrated yet.

\section{CONCLUSION}

Conclusions of this research are based on the findings and discussions and also refer to the research purposes. The conclusions are first, educational service quality at Economic Faculty of Universitas Negeri Semarang which covers administration, curricular, research, community devotion, extracurricular services based on the relevance, efficiency, effectiveness, accountability, responsiveness, creativity, productivity, academic capability, empathy, and appearance dimensions are mostly perceived quite good by the students. However, they have not met the optimal criteria. Generally speaking, the Economic Faculty students perceive the educational service quality in the area of good and fair criteria.

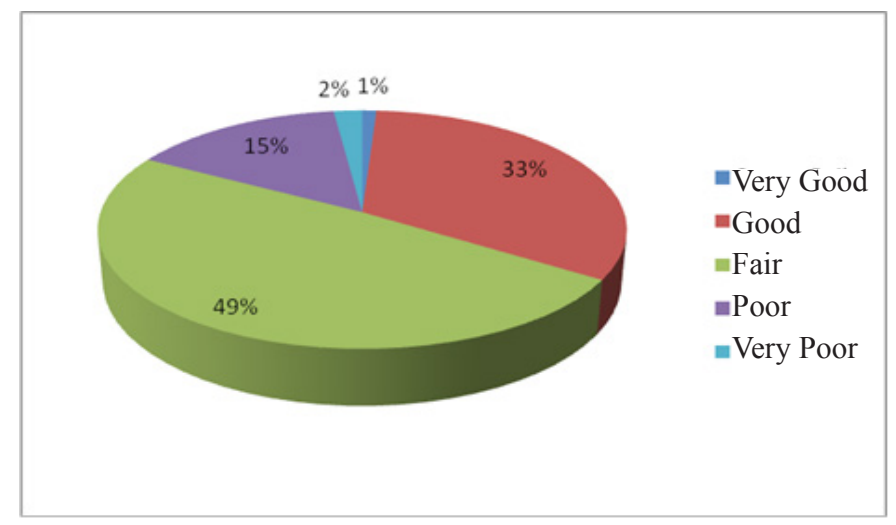

Graphic 6. Percentage of Extra Curricular Service 
Murwatiningsih / Analysis of Perceived Quality of Education...

Tabel 8. Percentage of Extra Curricular Service based on the Service Quality Dimensions

\begin{tabular}{llccccc}
\hline Variable & Measurement Criteria & $\begin{array}{c}\text { Very Good } \\
(\%)\end{array}$ & $\begin{array}{c}\text { Good } \\
(\%)\end{array}$ & $\begin{array}{c}\text { Fair } \\
(\%)\end{array}$ & $\begin{array}{c}\text { Poor } \\
(\%)\end{array}$ & $\begin{array}{c}\text { Very Poor } \\
(\%)\end{array}$ \\
\hline Extra Curricular & Relevance & 1 & 29 & 52 & 17 & 1 \\
Service & Efficiency & 1 & 26 & 55 & 15 & 3 \\
& Effectiveness & 1 & 39 & 44 & 13 & 3 \\
& Accountability & 1 & 26 & 54 & 18 & 1 \\
& Responsiveness & 2 & 31 & 51 & 13 & 3 \\
& Creativity & 1 & 36 & 45 & 16 & 2 \\
& Productivity & 1 & 29 & 52 & 17 & 1 \\
& Academic Capability & 1 & 45 & 40 & 12 & 2 \\
& Empathy & 1 & 34 & 45 & 18 & 2 \\
& Appearance & 1 & 35 & 53 & 9 & 2 \\
& Average & 1 & 33 & 49 & 15 & 2 \\
\hline
\end{tabular}

Source: data processed (2014)

Second, the administration service quality provided by the Economic Faculty of Universitas Negeri Semarang is perceived by the students as good in the relevance, accountability, responsiveness, productivity, creativity, academic capability, empathy, and appearance dimensions. Meanwhile, the efficiency and effectiveness criteria are perceived as quite good. Third, curricular service quality given by the Economic Faculty of Universitas Negeri Semarang is perceived by the students as good in the relevance, efficiency, effectiveness, accountability, responsiveness, creativity, productivity, academic capability, empathy, and appearance dimensions. However, the relevance dimension percentage is relatively high in the poor perception.

Fourth, research service provided by Economic Faculty of Universitas Negeri Semarang is perceived by the students as good in the relevance, efficiency, effectiveness, accountability, responsiveness, creativity, productivity, academic capability, empathy, and appearance dimensions. However, the poor perception is still relatively high in the relevance and effectiveness dimensions; Fifth, Community devotion service quality is perceived by the students in good criteria based on the relevance, efficiency, effectiveness, accountability, responsiveness, creativity, productivity, academic capability, empathy, and appearance dimensions. However, the poor perception is still relatively high in the dimensions of relevance and efficiency.

Sixth, extracurricular service quality provided by Economic Faculty of Universitas Negeri Semarang is perceived in the fair criteria by the students, based on the dimensions of relevance, efficiency, effectiveness, accountability, responsiveness, creativity, productivity, and empathy. In addition, the academic capability and appearance dimensions are perceived in the good criteria by the students. Suggestions given in this research are 1) the number of administration staff with proportional academic capability and professional in their duty needs to be increased to improve the administration service quality; 2) the head of department needs to improve the controlling function to create a more effective curricular service; 3 ) time management planning is crucially needed to improve efficiency and effectiveness in the research guidance service; 4) the important of coordination between department and the related parties (LP2M, UKM, HMJ, and others) to accelerate the community devotion service, hence, the quality will be reliable; 5) as an attempt to optimize 
extracurricular service quality, the activities selection must be very neat and appropriate based on the curricular service which support and 6) Continuous improvement which focuses on the customers' (students') needs and wishes. To achieve optimal criteria of the educational service quality, the Department/Study Program performance needs to be improved under the supervision of the quality control at the department and faculty level.

\section{REFERENCES}

Asia Week. 1999. Special report education. Available at: cnn.com

Brown, T. J, G. A. Churchil, Jr \& J. Peter. 1993. Improving the Measurement of Service Quality. Journal of Retailing. 69 (1)

Hasan, I. M. pokok-Pokok Materi statistik 1 (Statistik Deskriptif). Jakarta: Bumi Aksara.

Juran, J. M. 1995. Kepemimpinan mutu. Pustaka Binawan Presindo: Jakarta.

2002. Ekonomi dan Manajemen. Jurnal Riset. 2 (3). Ikatan Sarjana Ekonomi Indonesia (ISEI) Cabang Surabaya.
2003. Manajemen Mutu Terpadu. Jurnal Manajerial. 1 (2). Januari Jurusan Pendidikan Ekonomi FPIPS Universitas Pendidikan Indonesia.

Parasuraman, A. V., Zeithaml, A \& Berry, L. 1998. SERVQUAL: A Multiple-item Scale for Measuring Customer Perceptions of Service. Journal of Retailing. 64 (1).

Ross, J. 1993. Total Quality Management: Text, Cases and Readings. St Lucie Press. Deldray Beach, FL.

Sallis, E 1993. Total Quality Management. London: Kogan Page Philadelphia.

Simatupang, R. A. 2011. Analisis Hubungan Kualitas Jasa Terhadap Kepuasan Konsumen pada Lembaga Pendidikan Kejuruan. Jurnal Dinamika Manajemen. 2 (1).

Sudjana. 1992. Statistika. Bandung: Penerbit Tarsito.

Suwardi, R. 2001. Sistem Manajemen Mutu ISO 9000:2000 Penerapannya Untuk Mencapai TQM. Jakarta: Lembaga Manajemen PPM.

Tampubolon, D. 2001. Perguruan Tinggi Bermutu. Jakarta: Gramedia Pustaka Utama.

Tjiptono, F. 1998. Manajemen Jasa. Andi: Yogyakarta. 